4

\title{
EL ROL DE LOS MEDIOS EN LA CONSTRUCCIÓN DE PODER DE NÉSTOR KIRCHNER
}

\author{
EL APORTE DE CLARÍN Y LA NACIÓN \\ EN LA CONSTRUCCIÓN DE LEGITIMIDAD EN \\ LOS PRIMEROS MESES DE GESTIÓN
}

Jorge Ghigo 


\section{RESUMEN}

A partir del análisis de dos medios formadores de opinión de Argentina, como Clarín y La Nación, se indaga en la construcción de poder del ex presidente Néstor Kirchner en los primeros meses de gestión. Se examina cómo dos diarios tan disímiles operaron con una misma macroestrategia de comunicación, lo que contribuyó fundamental y eficazmente a asegurar la legitimidad del ex presidente, ausente en las urnas. Para ello, se conformó un corpus con más de 600 artículos periodísticos publicados entre el 25 de mayo y 24 de agosto de 2003, donde se identifican y sistematizan las principales estrategias de comunicación y el impacto de su operatividad, desde los aportes de las teorías de la enunciación, de la comunicación de masas y de los géneros periodísticos. La investigación pretende un enfoque innovador al superar las perspectivas del contexto político, social y económico con las que se intentara explicar el fenómeno, al introducirse en el análisis de los procedimientos utilizados desde el discurso periodístico para la construcción de representaciones que le permitieron a N. Kirchner generar "poder simbólico» y consolidar su imagen de manera rápida y efectiva.

\section{PALABRAS CLAVE}

$>$ discurso

$>$ poder

$>$ Néstor Kirchner

$>$ macroestrategia de comunicación

>opinión pública 
ABSTRACT

From the analysis of two media opinion makers from Argentina as Clarín and La Nación, this work explores the power construction's former President Nestor Kirchner in the first months in management. It examines how two such dissimilar daily operated with the same communication macrostrategy, contributing effectively to ensure fundamental and the legitimacy of the former President, absent in the polls. To this end, a corpus with over 600 articles published between May 25 and August 24, 2003, which identify and systematize the main communication strategies and the impact of its operation, from the contributions of the theories of enunciation, mass communication and media genres. The research seeks an innovative approach to overcome the prospects of the political, social and economic which try to explain the phenomenon, when introduced into the analysis of the procedures used from the journalistic to construct representations that allowed N. Kirchner generate «symbolic power» and consolidate its image quickly and effectively.

\section{KEY WORDS}

$>$ discourse

$>$ power

$>$ Néstor Kirchner

$>$ communication macrostrategy

$>$ public opinion 